УДК 378.4(476):[338+316.3]

Novikova I.V.

\title{
BUSINESS EDUCATION AS THE ENGINE OF SOCIOECONOMIC CHANGE IN FORMER SOVIET COUNTRIES: THE BELARUSIAN CASE
}

\section{Novikova Irina Vasilevna}

Doctor of Economic Sciences, Professor, Chief of the Department of Economics

The Academy of Public Administration under the aegis of the President of the Republic of Belarus 17 Moskovskaya St., 220007, Minsk, Republic of Belarus

E-mail:novikova@pac.by

\section{A bstrakt}

The article is devoted to some new areas of business education in the Republic of Belarus 1 whose emergence is a reaction to demand of the national economy in the course of social and economic development of the country at the beginning of the XXIst century. Opening of specialties of the second level of higher education (magistracy) is a result of the scientific researches carried out in the Academy of Management under the aegis of the President of the Republic of Belarus in 2009-2014.

Keywords: globalization; geoeconomics; managers; business education; private public Lpartnership; financial markets and institutes; corporate management.

Новикова И.В.

БИЗНЕС-ОБРАЗОВАНИЕ В ОБЕСПЕЧЕНИИ УСЛОВИЙ ДЛЯ СОЦИАЛЬНО-ЭКОНОМИЧЕСКОГО РАЗВИТИЯ: НА ПРИМЕРЕ РЕСПУБЛИКИ БЕЛАРУСЬ

Новикова Ирина Васильевна, доктор экономических наук, профессор, заведующий кафедрой экономической теории Академия управления при Президенте Республики Беларусь, Московская 17, Минск, 220007, Республика Беларусь

E-mail: novikova@pac.by

\section{Аннотация}

\footnotetext{
Статья посвящена новым направлениям бизнес-образования в Республике Беларусь, появление которых является реакцией на запрос национальной экономики в процессе социально-экономического развития страны в начале XXI века. Открытие специальностей второй ступени высшего образования (магистратуры) - это итог проведенных научных исследований, осуществленных в Академии управления при Президенте Республики Беларусь в 2009-2014 годах.

Глючевые слова: глобализация; геоэкономика; менеджеры; бизнес-образование; - государственно-частное партнерство; финансовые рынки и институты; корпоративное управление.
} 


\section{Introduction}

The world is currently undergoing the process of transformation from industrial to postindustrial economy which is characterized by totally different principles of the organization of production. Some countries have already finished the transition whilst some are still in the middle of it. One of the main characteristics of the new economy is the formation of the unitary geo-economic system which is growing out of globalization processes.

Globalisation draws the world economy that has recently been viewed as the web of national economic connected by the system of international division of labour as well as bilateral and multilateral economic and political relations, into the market economy. This process leads to the transformation of some of the parts of national economies into external economies through MNCs, regional groupings, specific economic and border zones, bilateral free trade agreements, cross-network clusters, etc. These parts then get separated from national economies and become closely intertwined as the elements of geo-economy. In the future these processes will lead to the creation of a unified world network economy and its infrastructure which key elements will be not the national economies but the very segments that having separated from them will form the world network economy, i.e. MNCs, transnational banks, insurance companies and all those elements that will service the world reproductive process regardless of the country of origin (the world financial, logistical, information system, etc.). It will be extremely hard for the majority of countries to 'break in' and fit in the new system as did the countries that followed the 'catching up' liberal model in the 1960s-1980s (e.g., South Korea and the countries of South-East Asia) [1].

These are the macroeconomic conditions under which the countries that have recently been state-controlled and, consequently, had no market institutions, or the experience of market relations, started their economic transformations. As the result, these economies have to solve two major problems:

1. restructure their national economies to create modern market relationships which match the processes occurring in the world economy and learn how to work under these conditions;

2. enter the world geo-economic space, i.e. participate in the processes of globalization and the formation of geo-economy.
The attempt to solve these problems has caused a tectonic shift in these economies. The social and economic transformations that have started in the countries of the former Soviet Union and Central and Eastern Europe affected major population groups. The 1990 s evidenced a dramatic economic decline, subsiding living standards followed by a demographic fall. Slowly and gradually most of these countries have started the transformation of property relations and their social and economic structure.

These transformations, in turn, required specialists who could implement the changes in real life. Thus, one of the derivatives of socio-economic transition was the need to train such specialists, particularly managers in new, earlier unknown economic specialties. It were them who were to implement the transformations and manage new economic entities such as insurance, financial, leasing companies, investment funds, ventures and so on.

The 'first wave' of existing specialists from former Soviet republics was retrained in the 1990 s by the World Bank, IMF,USIA, USIS, USAID, TACIS, TAEX, IREX, Fulbright programs, etc. The universities began altering the system of training at the Bachelor's level, started training of middle and senior managers, PR managers, marketing managers, etc., retrained/ trained new entrepreneurs, mostly those who had received a university degree (technical, medical, biological, etc.). At the same time most of the transformations that took place in the former Soviet Union were inconsistent and the newly established economic structures did not show considerable interest in the newly trained cadres.

The dynamics of economic indicators and tertiary education Belarus

At the start of economic restructuring in 1991 Belarus was known as the USSR 'assembly line'. At the time it was a country with a well-established agricultural and industrial base and a good system of secondary, tertiary, postgraduate and doctorate training. The transformational processes in the national economy introduced new requirements to graduates, particularly the ability to work in the managerial capacity.

In 2012 there were 54 tertiary educational establishments in Belarus with the total number of students reaching 428.4 thousand people (453 students per 10000 people). Approximately 39 percent of university graduates in 2002-2012 
were trained in Communications, Law and Economics or Management, Economics and Production (14-16 thousand graduates per year) [2]. A large share of these specialists in the structure of graduates was determined by changes in the structure of Belarusian GDP which required new kinds of specialists, particularly managers. While the ratio between the production and services sectors in Belarus in 2000 was 48.6 and 38 percent, by 2012 it changed to 47.2 and 42.5 percent respectively. The observed period was characterized by an intensive growth of employment in construction, trade, transport and communications, financial services, real estate, individual services to population, including communal and social services. The total change comprised 8.4 percent (from 33.2 percent in 2002 to 41.6 percent in 2012). At the same time, the share of employment in industry and agriculture in the total employment fell quite significantly, from 28.1 to 25.6 percent and from 15.2 to 10 percent respectively [2]. The distribution of employment between the state and private sectors also changed. The employment in the state sector fell almost by a quarter (24.1 percent) while the state sector expanded by more than a third: the growth comprised 34.6 percent [2].

The analysis of the distribution of organisations by the field of economic activity in 20112013 showed the 11.9 increase in the total number of companies. Of these, growth in construction equaled 13 percent, in trade -9.2 percent, in transport and communication -25.3 percent, in financial services $-\mathbf{1 7 . 3}$ percent, in real estate, renting and individual services to population 25.3 percent, in communal and social services to population -9.2 percent [2].

The distributional structure by the type of legal entity also changed. Out of the total $\mathbf{1 1 . 9}$ percent increase in legal entities, the number of commercial organisations grew by 12.9 percent and joint stock companies - by 4.7 percent (the number of open joint stock companies grew by 5.9 percent and the number of closed joint stock companies - by 3.2 percent). The newly created corporate structures need specialists in corporate governance. However, corporate structures in Belarus did not realize this need straight away which led to them experiencing an avalanche of management-related issues. The worst problems occurred when the entities tried operating at foreign markets and in 'conjunction' with foreign corporations. One of the recent examples is the creation of the Belarusian Potassium Company (BPC) as on the basis of the merger of the Belarusian company 'Belkalii'1 and the Russian company 'Uralkalii'. With the control of over 40 percent of the world potassium market, BPC was indeed one of the biggest players in the industry. Due to the incompetence of its management, BPC brought down the world potassium market in 2013. As the enterprise was one of the biggest Belarusian corporate taxpayers, its collapse created a hole in the country's budget that has not yet «been plucked». The main legal form private companies in Belarus take is the limited liability company. It is the very type of legal entity that the small business in Belarus prefers; for a limited liability company the competence of managers is crucial. The number of limited liability companies has grown by a record 31.2 percent in 2011-2013 [2]. Thus, the dynamics of GDP, total, occupational and sectoral employment, as well as the shifts in the distribution of entities by economic activity and by the legal form show the urgent need for change both in the structure and in the quality of training of specialists at the tertiary (university level).

The changes have to be introduced not only into the curriculum and syllabus of new specialties. The established programs that have been taught for quite some time by Belarusian business schools have to be amended, particularly in terms of the weighting of the subjects that are taught in order to form the program that provides future managers with the best skill set. But the most complicated task is opening new postgraduate specialties; particularly at the Masters level since those who graduate at this level will mostly be employed at relatively high-powered managerial positions.

The complexity of the task of creating effective Masters programs is not only in the development of new curriculums. The main problems Belarusian business schools face are the lack of highly qualified academic staff capable of teaching new specialties; the lack of the teaching methodologies for the new specialties; and the lack of motivation of the academic staff (universities in Belarus practice the leveling method which does not encourage innovative thinking and development of new modules). The number of doctoral students (the main cadre reserve for univer-

\footnotetext{
${ }^{1}$ Belarusian Potassium

${ }^{2}$ Ural Potassium.
} 
sities) fell by 25.4 percent in 2001-2012 and so did the completions (-27.1 percent). The number of research organisations that have doctoral (adjunct) programs fell by 2.8 percent and the number of doctoral students (adjuncts) in these organisations fell by 27.3 percent. The number of admissions in these organisations fell by 51 percent, the level of completions decreased by 43 percent; in particular, the number of doctoral students at economics and management-related specialties fell by 15.8 percent [2].

Low wages of the academic staff is another demotivating factor. The statistics shows that the average nominal monthly wage in education was only 75.6 percent of the average nominal monthly wage in the economy while the wages in financial services were $\mathbf{1 6 6 . 1}$ percent and in the real estate, rent and personal services to population $-\mathbf{1 1 7}$ percent of the national average. The obvious result of such mismatch is the flow of the best potential cadres from education to better paying sectors. Another source of drainage is increasing migration to neighboring countries (Russia, Poland) which offer better salaries to academics.

Another impediment is the currently used system of awarding doctorate degrees which was inherited from the Soviet Union. Belarus still has the Higher Attestation Committee - an obsolete structure that has the power to cancel (or not confirm) any doctoral (or honorable doctoral) degree awarded by universities or research organisations. The viva procedure is cumbersome, highly bureaucratic and takes a very long time. As the result, young prominent specialists prefer working in industry or opening their own businesses to joining doctoral programs, which leaves the education starving for people.

However, regardless of these hardships, Belarusian business schools by the end of the 20oos managed to employ some West-trained lecturers and professors; some countries developed summer schools for re-training lecturers in management-related subjects. These would then teach undergraduate students.

Training managers for new economy the experience of the Academy of Public Administration under the Aegis of President of the Republic of Belarus

One of the key needs for every country which wants to 'fit' into a forming geo-economic structure is to form a new generation of managers and government officials who will be able to conduct the economic transformations and support the structural changes in the economy aimed at increasing its competitiveness at global markets. They must be able to transform the existing system of government economic regulation that was formed in the country during the 2oth century under the conditions of the industrial era. Now as the era is changing, so should the regulatory model. One of the major elements of this shift is the establishment of the state-private partnership.

Economic theory defined state-private partnership as the institution which includes a set of formal and informal rules under which the cooperative activities of the state and private business are conducted. It assumes the state and the business being equal parties who realize their own interest for the society's common good. The public-private partnership includes a wide variety of business models and relationships. In the most general understanding the term is used every time business resources are used to satisfy the common needs. The resources may vary from capital to know-how and managerial experience. Each state has its own definition of common needs. These may include anything the state needs parks, roads, and even such, in fact, economic sectors as health services, energy, communication or real estate. The main goal of the state-private partnership is to attract the resources of business into infrastructure development projects and the improvement of the quality of services. In case of Belarus it is also the development of innovative economy which is considered one of the main factors of maintaining the sustainable economy in the country. The nature of the state-private partnership involves redistribution of responsibilities and risks in the development of the sectors which have traditionally been considered the state zone of responsibility - the infrastructure, science and innovations.

Some elements of the state-private partnership are currently being studied in the course of more general educational programs within the system of retraining and qualification enhancement of the civil servants. The Academy of Public Administration under the Aegis of President of the Republic of Belarus bears the major load as the leading educational establishment in the system of re-training and qualification enhancement of civil servants.

Up until 2011 the public-private partnership was not considered a recommended subject for 
training within this system, no independent educational programs or re-training courses existed. In 2011 the Academy opened a new specialty 'Management of investment projects within the public-private partnership' which was aimed primarily at training the specialists who possess fundamental knowledge of the public-private partnership, critically analyze information and be capable of developing new knowledge that will help to make crucial investment-related management decisions. The new task the Academy set was to bring up a new generation of civil servants who understand the nature of the public-private partnership and can manage investment resources within its business models.

The curriculum of the 'Management of investment projects within the public-private partnership' program is a Masters level program that includes the following major modules:

public-private partnership in the national economic system;

- management of investment projects;

- forms and mechanisms of the implementation of the public-private partnership;

- the legal basis of the state-private partnership and fighting corruption;

- the economics of development;

- strategic management;

- organizational development and change management;

- business estimation and asset management;

- situational analysis and modeling of management decisions;

- macroeconomic analysis and the state of the financial market in the Republic of Belarus.

The students submit three courseworks and defend a Masters dissertation in the course of study.

This training program does not have close analogues in the country. Based on traditional programs in state-private partnership from leading world universities, the program offers the students extensive analysis of foreign business by the means of case-study analysis, discussions, workshops, business games, analytical project seminars and other interactive forms of study.

Since Belarus has a significant deficit of knowledge of the state-private partnership, the specialists capable of managing investment resources are supposed to be in demand in every sector of the national economy. The program was opened to match the new Law on the Public-Private Partnership that was supposed to be passed by the Parliament in 2012. But in this particular case the road to Hell was indeed paved with good intentions. The law has not been passed yet, it is planned that it will finally be passed in 2014, though the Investment Code of the Republic of Belarus has the article "on Concession" which is one of the forms of the state-private partnership, so in theory some graduates could have, in theory, found the jobs even now.

Another problem for the program is the underdevelopment of Belarusian financial market. As it was mentioned earlier, the world economy is experiencing significant transformations. Some of the most important changes take place in the financial markets, both globally and regionally. Increased openness of Belarusian economy and its growing integration into the world economy determines an increasingly important role of the financial infrastructure. The change of the technological mode in the beginning of the 21st century together with the necessity to modernize the economy require the sources of financing for investment projects and development of financial infrastructure in order to decrease transaction costs and achieve stable growth rates.

The operations of financial institutes involve a set of complex multilevel contractual relationships, a large number of transactions, the distribution of assets and the formation of investment resources for the growth of the economy and its integration into the EurAsEC ${ }^{1}$. All these processes have to be directed and managed.

It is widely accepted that the development of the national economy these days is determined by the purposeful influence on and management of the development of financial markets and institutions since it determines the pace and level of development of the national economy.

Though the processes of economic transformation have been implemented in Belarus since 1991, its financial market is mostly represented by banks. Every five years the government passes the Program of Socio-Economic Development which is indicative in nature. The latest program for 2011-2015 period was passed in 2010 and became the basis for the government Enactment No.932 (11.07.2011) and the measures for its implementation.

One of the sections of the Measures is devoted to the development of financial markets which includes the following subsections:

\footnotetext{
1 ЕврАзЭС - экономический союз между Россией, Беларусью и Казахстаном.
} 
1. Formation of competitive financial market.

2. Increased reliability, competitiveness and efficiency of the national insurance market and the level of capitalization of insurance companies.

3. Development of institutions of financial intermediation and financial derivatives.

4. Providing conditions for the development of integration processes that improve and expand areas of cooperation of national securities markets and derivatives markets with global financial institutions and structures.

In general, these subsections contain 20 different measures which are viewed as the means of the launch of effective mechanisms of the financial market and its institutions, which ultimately have to fulfill the Socio-Economic Development of the Republic of Belarus for 2011-2015. Thus the government of Belarus faces complex conceptual, institutional economic and legal challenges in the process of formation and development of financial market.

To successfully implement the challenges, the specialists in management of financial markets and institutions have to be trained. To address the need, the Academy decided to open the "The development management of financial markets and institutions' specialty aimed at training the specialists possessing the knowledge in the area of the development of the financial infrastructure and being capable of managing the equitable integration of financial markets and institutions in the Single Economic Space ${ }^{l}$ and the financial space of the world economy.

Opening of this specialty will help form new managers who have an understanding of the nature and essence of modern management in the area of the development of financial markets and institutions and are capable of conducting expert-analytical activities, develop strategic documents in the field of development of the financial sector and ensure their implementation.

The specialists in the field of development of financial markets and institutions, will, in fact, be in demand in every segment of the financial market. This is due to the fact that in the 1990s during the formation of financial market institutions - finance in economic development;

- financial instruments and markets;

- strategic and financial management;

\footnotetext{
${ }^{1}$ С 2012 года Беларусь совместно с Россией и Казахстаном в рамках ЕврАзЭС приступили к формированию Единого экономического пространства, предполагающего свободное перемещение не только товаров, но и труда и капитала.
}

- globalisation and economic development; macroeconomic analysis and the state of financial markets of the Republic of Belarus;

- financial management of international corporations;

- fundamental and technical analysis of financial markets;

- IFRS;

- information systems and technology in financial management;

- the influence of political business-cycles on stock markets;

- management of risks in companies and financial institutions.

The students will have to submit three courseworks and defend a Masters dissertation.

The feature that distinguishes the program is its focus on:

1. Patterns of development of modern financial infrastructure and its role in investment in national economic development

2. Determining the optimum structure of various entities of financial market for a given level of development of the national economy;

3. Minimization of transaction costs in the economy based on modelling the behaviour of the subjects of the financial infrastructure;

4. Managing the development of financial institutions to achieve the desired economic growth and social development;

5. Development of institutions of financial intermediation and financial derivatives;

6. Providing conditions for the development of integration processes that improve and expand areas of cooperation of national securities markets and derivatives markets to global financial institutions and structures.

Under current conditions the process of globalization is advancing rapidly in the global economy with the end point being the formation of a global network of world economy - geo-economics whose main players will be large companies. Therefore, one of the major processes taking place in the modern economy is the enlargement of players with their configuration constantly changing. In these circumstances, the state can either promote or oppose this process as by itself it is no longer a subject of the world economy.

These days the Belarusian government promotes consolidation of our businesses - through the formation of holding companies, joint corporations, etc., respectively, there is a problem of corporate governance in these structures. The need 
for corporate governance is caused primarily by the fact that the property belongs to the business as principals (owners, investors) while the property management rights are delegated to agents - the board and management. This situation gives rise to the asymmetry of information and related agency costs leading to management actions that are not designed to meet the interests of the owners or are directed in a way that causes harm to the interests of the owner. An example of a situation of inadequate corporate governance, as we noted above, is a clash of interests "BPC" and Russian "Uraltreyding" in August 2013. That is why the training of specialists in the field of corporate governance is extremely relevant today.

The main purpose of opening a specialty "Corporate Governance" is to train professionals with deep knowledge in the field of corporate governance that meet the needs of the national economy and provides the conditions for its development and integration in the EurAsEC, analytical skills and ability to synthesize new knowledge to make meaningful management decisions in corporate governance. Also, the opening of this specialty will form a new generation of managers who have an understanding of the nature and essence of modern management within a corporation.

Various systems of corporate governance may form depending on the characteristics of the ownership structure, its degree of concentration of the mechanisms of financial regulation, capital markets and national company law. Despite sharing the general patterns in corporate governance, the Belarusian economy will have some specificity due to its legislation. But in connection with the integration processes within the EurAsEC the problem of the understanding of corporate governance and decision-making that fits a certain economic situation arises, for the lack of knowledge on corporate governance will lead our economic entities in these conditions to a simple incorporation by Russian corporations or corporations from other countries. Thus, the main purpose of opening the program is to prepare managers who understand the nature and essence of modern corporate governance for the development of the national economy.

Experts in the field of corporate governance will, in fact, be in demand in all segments of our economy, because, as it was mentioned above, the process of consolidation of players in the global economy is under way. Accordingly, there is enlargement of capital and changes in its structure through the deepening separation of capital-ownership from capital as a function.

Within the specialty of "Corporate Governance" the list of core modules to be studied includes the following subjects:

- models and mechanisms of corporate governance: theory and practice;

- corporate finance;

- risk management of corporation;

- IFRS;

- asset management of the company;

- corporate information systems and technologies;

- legal basis of corporate governance;

- transfer pricing in a corporation;

- corporate governance in international companies;

- organisational development and management of change in corporations;

- corporation management.

\section{Conclusion}

Thus, despite the difficulties that exist in the training of managers, the Academy of Management under the President of the Republic of Belarus is working hard to open of new specialties at the Masters level. The training of specialists will help create a civilized market relations in the Republic of Belarus, facilitate its full integration into the global environment, which in turn, will provide not only economic but also social development of the newly independent republic.

\section{REFERENCES:}

1. Novikova I. Why is Korea not afraid to enter geo-economy? // TheKoreanTimes. October 22. 2010. P. 12.
2. Annual Statistics of the Republic of Belarus. Minsk, 2013. URL: http://www.statistics2013. org.by (date of access: January 12, 2014) 